\title{
Transportation Attache's Role in Fraudulent Certificates of Indonesian Seafarers in Singapore Area
}

\author{
Dewi, I.S ${ }^{1}$, Seno, $\mathbf{A}^{\mathbf{2}}$, Humantaristi, $\mathbf{S}^{\mathbf{3}}$ \\ ${ }^{1}$ Lecturer of Port and Shipping study program of Politeknik Ilmu Pelayaran Semarang \\ ${ }^{2}$ Lecturer of Marine Engineering study program of Politeknik Ilmu Pelayaran Semarang \\ ${ }^{3}$ Student of Port and Shipping study program Politeknik Ilmu Pelayaran Semarang \\ Jl.Singosari 2A, (024) 8311527, 8311529 \\ e-mail: irmashinta@pip-semarang.ac.id ; abdiseno@pip-semarang.ac.id ; \\ humsyanandia@gmail.com
}

\begin{abstract}
The concept of Indonesia as Global Maritime Nexus (GMN) in the appliance divided by 5 (five) sectors, which are culture, economy, connectivity, diplomacy and security. The competence of human resource, i.e: seafarer needs to be fixed, especially in the quality. The increasing of life necessities creates lot of seafarers and society choose instant method to make seafarer false certificate. Transportation Attache of Indonesian Embassy in Singapore as one of the important stakeholder in signing seaman book in Singapore area has important role to solve seafarer fraudulent certificate. This research has purpose to know the causes as well as the impact of fraudulent seafarer certificates around Singapore area, and to know the mechanism done by Transportation Attache of Indonesia Embassy in Singapore. This research used qualitative method. Observation, interview and literature studies are done to obtain the data. To test the data validity, researcher performed research-extension and triangulation method. The results of this research are: 1) the cause of fraudulent seafarer certificates is seafarers' deviant social behaviour, the weak system of Indonesian seafarer online certification, and the opportunity and chance for seafarers to do fraud. 2) The impacts from this case are a lot of seafarers face hard time to find jobs in Singapore shipping companies, the lack of trust from abroad companies to recruit Indonesian seafarer, also blacklist toward Indonesian seafarers with certain ranks in several companies. 3) The efforts to solve this case are to strictly apply the monitoring and checking function along with Minister Instruction number 4 year 2018, to do issue verification with the related training institution and cooperate with State Cyber and Code Agency that is called Badan Standardisasi Siber Nasional (BSSN) to strengthen the security system of seafarer certification.
\end{abstract}

Keywords: Global Maritime Nexus (GMN), Human Resource, Seafarer, Transportation Attache, Certificate, Fraudulent, Indonesian Embassy, State Cyber and Code Agency

\section{Introduction}

The President of Indonesia stated that the maritime sector is the focus of the Indonesian state by emphasizing the 5 (five) main pillars of the World Maritime Axis, namely; maritime culture, maritime economy, maritime connectivity, maritime diplomacy, and maritime security.

Based on data from the official seafarer.go.id website on March 20, 2020, the number of seafarers has increased every year from 1,062,193 seafarers in 2019 to

This paper is presented in The $4^{\text {th }}$ International Conference on Maritime Education and Training 80 October $8^{\text {th }}, 2020$, Makassar, Indonesia 
$1,165,869$ in 2020 , therefore it can be concluded that Indonesia has increased the number of seafarers rapidly. from various education and training institutions in Indonesia.

Seafarers sail after completing competency training at the education and training institutions and are required to sign a Sea Work Agreement (PKL) and sign-on at the port authority where the seafarers will board the ship, as well as at the Embassy of the Republic of Indonesia which has a Transportation Function before sailing.

The Indonesian Embassy in Singapore is a representative of the Indonesian Ministry of Foreign Affairs located in Singapore and is tasked with taking care of Indonesian citizens who live, work and visit in Singapore. The Indonesian Embassy in Singapore is divided into several functions and attaches according to the Ministries in Indonesia and takes care of their respective fields. The Transportation Attaché has service duties for seafarers starting from signing on, signing off, making seafarers' books, extending seafarers' books, and making Indonesian-Singapore Seafarers' Cards at the Indonesian Embassy.

Seafarers are required to bring their maritime certificates, namely Certificate of Competence $(\mathrm{CoC})$ and Certificate of Endorsement $(\mathrm{CoE})$, to be verified and declared that their certificate is genuine for the seafarers' service process. The increasing need for seafarers, insurance and guaranteed living costs have led many seafarers and the public to choose shortcuts to fake maritime certificates.

Until now, there has been no specific research regarding the prevalence of fake maritime certificates, nor has it explained the role of the government, in this case the Transportation Attaché in handling them in Indonesia.

In fact, with the application of the Ministerial Instruction to officials at the Ministry of Transportation who are assigned overseas regarding the Fake Maritime Documents that came out in the same year, there is still miscommunication and gaps in related stakeholders and their application in dealing with this case. Because of this, researchers conducted research on the role of the Indonesian Embassy in Singapore's Transportation Attaché in resolving cases of fake maritime certificates for Indonesian seafarers in Singapore with a research entitled, "The Role of Transportation Attaches of the Indonesian Embassy in Singapore in Resolving Fake Maritime Certificate Cases for Indonesian Seafarers in Singapore Territory."

The problems examined in this thesis are as follows:

1.1. What are the reasons for the prevalence of fake maritime certificates for Indonesian seafarers in Singapore?

1.2. What are the implications for the proliferation of fake maritime certificates for Indonesian seafarers in Singapore?

1.3. What steps are taken by the Transportation Attaché at the Indonesian Embassy in Singapore to deal with cases of fake maritime certificates?

\section{Research Method}

The approach used in this study is a qualitative approach. With this approach, the researcher intends to collect data and observe carefully the aspects related to the problem under study so that they will obtain data that supports the analysis process. The data obtained are then processed and analyzed further on the basis of the theory that has been studied in order to obtain a description of the object and conclusions can be drawn about the problem under study.

The focus of this research is to examine the role of the Transportation Attaché in dealing with cases of counterfeit certificates. This research was carried out as long as the 
researchers carried out land practice, starting from the time the researcher started land practice on July 122018 until the researcher finished land practice on December 14, 2018. The research site was the Transportation Attache of the Indonesian Embassy in Singapore.

Researchers in this case grouped data sources into three categories to facilitate data processing: Incidents, The research subjects, witnesses of the events being studied,and Documents, namely written files related to the events under study, for example books, pictures, archives, and others.

Data collection techniques are techniques used to obtain data and information needed in research. Data collection techniques are the most strategic step in research, because the main purpose of research is to get data [4]. Therefore, researchers used the following techniques to obtain the required data.This observation or observation technique is based on direct experience. Observation is defined as a careful and systematic observation, carried out repeatedly on an event. The researcher carried out the observations by fully participating, in this case, becoming a full member of the group he was observing, namely when he was a ground practice cadet at the Transportation Attache of the Indonesian Embassy in Singapore. Researchers interviewed data sources; Transportation Attache of the Indonesian Embassy in Singapore, Assistant A.tase of Transportation of the Indonesian Embassy in Singapore, One of the seafarers who had found a case of fake diploma on a colleague.

The documents that the researchers used as data sources that supported this research were books in library, IMO publications, research reports on the Mona Lisa Project, and related laws and government regulations. To obtain relevant data, the researcher checks the validity of the research data by: Extension of Observations, The researcher stayed at the research site until the saturation of data collection was reached, from 16 August 2017 to 21 October 2018. Triangulation Method, the researcher compared the observation data with the interview data, the interview data with the literature study data, and the literature study data with the observation data.It describes all the incidents or incidents that occurred at the Transportation Attache of the Indonesian Embassy in Singapore which are related to the issues discussed in this thesis. Observations and views on existing data starting from the main problems that occur, reading data sets, are studied based on theories that can provide the best solutions to problems so that problems that arise can be resolved with solutions.

\section{Result and Analysis}

\subsection{Research Result}

3.1.1. The cause of the rampant fake maritime certificates for Indonesian seafarers

From the results of the observations carried out, it was found that three factors that caused the rise of fake maritime certificates were the deviant social behavior of seafarers, the weak online Indonesian seafarers certification system, and the opportunities and opportunities for fraud.

Social behavior and individual personality are not formed by themselves, but there are several factors that influence them. These factors can come from the individual's environment, psychological, biological, and environmental factors. Evidence of this deviant social behavior is that, when the researcher performed the task related to the sign on and sign off, there was one of the suspected seafarers who could not explain the difference between a Certificate of Endorsement and a Certificate of Competence, and their uses.

Ths paper is presented in The $4^{\text {th }}$ International Conference on Maritime Education and Training 82 
The Directorate General of Sea Transportation (DJPL) has collaborated with the National Cyber and Crypto Agency (BSSN) to carry out a Security Assessment of the Online Seafarers Certification System Application which was built in 2016 by conducting investigations within the scope from June 2018 to October 2019. Certificate producing syndicates The existing has been able to penetrate the firewall on the seafarer.dephub.go.id site and unsuspend the seafarer's registration number that has been suspended previously. The evidence that this certification system is still weak is, from the seafarers 'database which has been frozen, there are several fake certificate holders whose seafarers' numbers are still not frozen, and after being frozen, a week later when they are checked it is normal.

Opportunities and opportunities for seafarers to commit fraud are also the cause of the proliferation of fake maritime certificates. This can be proven from one of the confessions of the seafarers who have been interrogated and from the modus operandi carried out by one of the seafarers' syndicates who have been caught in North Jakarta. Their mode of action is to provide offers to prospective seafarers who want to sail with fake skill certificate manufacturing services by providing original blank guarantees made by the Public Company for the Printing of Money of the Republic of Indonesia (PERURI) as well as a certificate with a number registered online on the seaman website.dephub.go .id

The validity of this data source must be tested for the validity of the data. To strengthen the results of this observation data, data triangulation was carried out. After observation, an interview was conducted with the Transportation Attaché on August 15 2018. He stated that, "the prevalence of fake certificates is seafarers who deviate from the existing mechanism." The rise of fake certificates is also acknowledged because the Ministry of Transportation's system is still weak and still in the development stage, especially on the seaman.dephub.go.id website which is commonly used to check seafarers' numbers. Meanwhile, Ditkapel itself has evidence that the modus operandi of fake maritime certificates is also the result of opportunities due to weak security in Transportation.

Literature study was conducted to strengthen these findings. This data was taken by researchers to support this research regarding the causes of the rampant fake certificates from January 2018 to June 2018.

3.1.2. The impact of the causes of the rampant fake maritime certificates

The rise of fake maritime certificates for Indonesian seafarers has had a huge impact not only nationally, but also internationally and within Singapore itself. Based on the results of observations, the impact of the cause of the rampant fake maritime certificates is that many seafarers find it difficult to find work in Singapore shipping companies, the lack of trust from foreign companies to recruit Indonesian seafarers and blacklisting of Indonesian seafarers with a certain rank in certain companies.

This data is also supported by an interview with a sailor whose crew held a fake diploma. The results of the interview stated that, "one bad sailor, another was affected as well." He referred to cases of marine certificates that were suspected and by superiors and companies, the performance of seafarers with fake maritime certificates was less than other seafarers.

A literature study was also carried out by looking at the number of demand for certificates that did not increase and tended to be stagnant. The number of sign on indicates that the number of seafarers being recruited and boarding ships, but because it is stagnant, means that shipping companies in the Singapore region still do not want to recruit in large numbers because they are aware of the rampant cases of fake maritime certificates.

Ths paper is presented in The $4^{\text {th }}$ International Conference on Maritime Education and Training 83 October $8^{\text {th }}$, 2020, Makassar, Indonesia 
3.1.3. Steps taken by the Transportation Attache of the Indonesian Embassy in Singapore to address cases of fake maritime certificates

The case of fake maritime certificates has had a lot of impact on the parties concerned, therefore, the Transportation Attaché of the Indonesian Embassy in Singapore together with the Directorate of the Executing Agency and the Ministry of Transportation also took firm action and steps to resolve this case. The results of the literature study show that the government, in this case the Ministry of Transportation, has issued a policy with the Ministerial Instruction (IM) number 4 of 2018 concerning Supervision of Seafarers' Documents. This policy contains the implementation of the supervision of seafarers 'certificates as regulated in Article 5 and Article 6 of the Minister of Transportation Regulation Number PM 70 of 2013 concerning Education and Training, Certification and the Seafarers' Guard Service. This instruction contains an appeal for increased supervision through online and manual inspection of marine documents in accordance with the provisions, based on inspection and verification of the validity of marine documents. This examination includes examinations using online databases, physical examinations of maritime documents by means of being seen, touched and interpreted, examinations using special tools and conducting clarifications with the Sub-Directorate of Maritime Affairs, Directorate of Shipping and Maritime Affairs, Directorate General of Sea Transportation. This examination also includes examinations during the marine education and process, as well as examinations when there are reports or complaints from the public, institutions, and seafarers against marine documents that are suspected of being unsuitable. based on inspection and verification of the legality of maritime documents. This examination includes examinations using online databases, physical examinations of maritime documents by means of being seen, touched and interpreted, examinations using special tools and conducting clarifications with the Sub-Directorate of Maritime Affairs, Directorate of Shipping and Maritime Affairs, Directorate General of Sea Transportation. This examination also includes examinations during the education and maritime processes, as well as examinations when there are reports or complaints from the public, institutions, and seafarers against marine documents that are suspected of being unsuitable. based on inspection and verification of the legality of maritime documents. This examination includes examinations using online databases, physical examinations of maritime documents by means of being seen, touched and interpreted, examinations using special tools and conducting clarifications with the Sub-Directorate of Maritime Affairs, Directorate of Shipping and Maritime Affairs, Directorate General of Sea Transportation. This examination also includes examinations during the education and maritime processes, as well as examinations when there are reports or complaints from the public, institutions, and seafarers against marine documents that are suspected of being unsuitable. inspection using special tools and clarification with the Sub-directorate of Maritime Affairs, Directorate of Shipping and Maritime Affairs, Directorate General of Sea Transportation. This examination also includes examinations during the education and maritime processes, as well as examinations when there are reports or complaints from the public, institutions, and seafarers against marine documents that are suspected of being unsuitable. inspection using special tools and clarification with the Sub-directorate of Maritime Affairs, Directorate of Shipping and Maritime Affairs, Directorate General of Sea Transportation. This examination also includes examinations during the education and maritime processes, as well as examinations when there are reports or complaints from the public, institutions, and seafarers against marine documents that are suspected of being unsuitable.

Ths paper is presented in The $4^{\text {th }}$ International Conference on Maritime Education and Training 
After the examination is carried out, the related party will give strict sanctions in accordance with the provisions of the laws and regulations on the holder of maritime documents issued illegally or to report to law enforcement officials

Based on the same case that occurred in North Jakarta, the Ministry of Transportation collaborated with the Police to coordinate cross-sectoral with the police. In this case, the Transportation Attache of the Indonesian Embassy in Singapore also coordinates with the Batam Police and Riau Police to resolve cases of fake maritime certificates. This cross-sectoral coordination is very beneficial for both parties to improve communication and coordination for the Ministry of Transportation and the Police. Crosssectoral coordination also covers the implementation of exposure to the development of case disclosures and coordination.

The next effort is to verify the validity of the issuance of certificates by maritime education and training institutions that have been approved by the Ministry of Transportation. Through the Transportation database and the database from the related Education and Training Institute, evidence and statements will be found that the seafarers are truly competent with a certificate or have never undergone maritime training.

From the Ministry of Transportation, by ordering government institutions under it, he urges to tighten the process of issuing a Sailing Approval Letter by checking the validity of the Seafarer's Certificate online as well as a physical examination that has been carried out within the scope of the Transportation Attaché.

The Ministry of Transportation also collaborates with the National Cyber and Crypto Agency (BSSN) in order to strengthen the security system for seafarers' certification by limiting access to certificate application servers in the form of a Virtual Private Network (VPN). In addition, the Transportation Attache of the Indonesian Embassy in Singapore also urges shipping companies to update and check the seaman.dephub.go.id website first before hiring seafarers.

\subsection{Analysis}

3.2.1. The deviant social behavior of seafarers.

Based on the results of observations while researchers conducted ground practice at the Embassy of the Republic of Indonesia in Singapore, one of the factors causing the rise of fake maritime certificates is the social behavior of sailors who want everything to be instantaneous in this digital era. Social behavior itself is behavior that affects each other on the response received itself. Social behavior can be shown through beliefs, feelings, actions towards others. Social behavior according to the Big Indonesian Dictionary (2001: 859), namely "Responses or individual reactions to stimuli or the environment". Individual responses or reactions can become behavioral patterns that can be formed through the process of habituation and reinforcement by conditioning the stimulus (Conditioning) in the environment (Environmentalistic). Not all behavior can be observed objectively or sensually by the eye, but behavior can also be observed from behavior that is not real or not from the sense of sight as well. Social behavior is divided into two, namely behavior that is visible to the eye (over behavior, for example working, crying) and behavior that is not visible to the eye (covert behavior) such as thinking, feelings, emotions, attitudes, etc.). [5] and others). [5] and others). [5]

Social behavior and individual personality are not formed by themselves, but there are several factors that influence them. These factors can come from the individual's environment, psychological, biological, and environmental factors.

Ths paper is presented in The $4^{\text {th }}$ International Conference on Maritime Education and Training 
It is this social behavior that makes these fake diploma syndicates flourish, as well as the many sailors who use fake certificates. The covert behavior shown by the attitude and manner of sailors who carry fake certificates so that they can immediately board a ship as well as demands from the environment to get a job make sailors even more incessant to hold these fake certificates.

This was also supported by Sudiono as the head of the Directorate of Shipping and Maritime Affairs (Ditkapel) at the online seminar and discussion regarding the Circulation of False Seafarers' Certificates on June 25, 2020. He argued that social behavior is a reinforcing factor that makes sailors and certain individuals take advantage of current environmental conditions to get a certificate and immediately on board.

The impact of this social behavior is that seafarers become uncompetitive and also make different reactions for each sailor, but most of the seafarers have the same mindset, that is, they are reluctant to continue higher maritime training. This can happen because they see that between original certificate holder seafarers and fake certificate holder seafarers have insignificant differences, and seafarers with fake maritime certificates also have backups for their unsuspend seafarers' numbers and low costs because they do not need to follow official maritime training.

Efforts made to reduce deviations in social behavior are to implement a supervisory function in accordance with Ministerial Instruction No. 4 of 2018. This examination includes examinations using online databases, physical examination of marine documents by being seen, touched, and stretched.

3.2.2. Weak online seafarer certification system

Before seafarers can make payments for an up and down certificate process, they must attach a certificate and agreement for inspection. This certificate must be checked by the Transportation Attaché or the Assistant Transportation Attaché in accordance with the provisions stipulated in the Instruction of the Minister of Transportation of the Republic of Indonesia number IM 4 of 2018 concerning Supervision of Maritime Documents. One of the considerations for the issuance of this instruction is that there are many certificates that are not issued legally by Dirjenhubla and are used to work on ships, as well as to continue maritime education and training. This Ministerial Instruction is addressed to relevant officials, including Transportation Attaches at the Indonesian Embassy to increase supervision through online and manual examinations of maritime documents in accordance with the provisions, based on inspection and verification of the validity of maritime documents based on the scope of supervision and inspection related tasks, giving strict sanctions according to the provisions of laws and regulations to holders of maritime documents issued illegally and reporting to Law Enforcement Officials, reporting the results of supervision and inspection of maritime documents to the Minister Transportation through Dirjenhubla and Kabadan BPSDM. This instruction came into effect on May 21 2018 and in its implementation, the Transportation Attaché also reports how many fake diplomas were detected in a month in a monthly report to the Minister of Transportation. provide strict sanctions in accordance with the provisions of laws and regulations to holders of maritime documents issued illegally and report to Law Enforcement Officials, report the results of supervision and inspection of maritime documents to the Minister of Transportation through Dirjenhubla and Kabadan BPSDM. This instruction came into effect on May 212018 and in its implementation, the Transportation Attache also reports how many fake diplomas were detected in one month in a monthly report to the Minister of Transportation. give strict sanctions in accordance with the provisions of laws and regulations to holders of maritime documents issued illegally and report to Law

Ths paper is presented in The $4^{\text {th }}$ International Conference on Maritime Education and Training 86 October $8^{\text {th }}$,2020, Makassar, Indonesia 
Enforcement Officials, report the results of supervision and inspection of maritime documents to the Minister of Transportation through Dirjenhubla and Kabadan BPSDM. This instruction came into effect on May 212018 and in its implementation, the Transportation Attaché also reports how many fake diplomas were detected in a month in a monthly report to the Minister of Transportation.

All forms of seafarer certificate are held by the Procurement Process of the General Affairs Section of the DJPL through PT PERURI. Blanks printed by PT. Peruri is stored in the General Section of the DJPL Warehouse and distributed to the Ditkapel according to a letter from the request of the Directorate General of Civil Engineering based on the Office Memorandum of the Maritime Affairs Sub-Directorate, then it is recorded and made an acceptance report and stored in the TU Warehouse of the Directorate General of Execution. Every time there is a request for a blank from the UPT Diklat, the Maritime Affairs Subdit will coordinate (open a warehouse) with the TU Ditkapel and make an official report on issuing a blank Each form that has been distributed to the UPT Diklat / Operators must be registered online according to the SOP and can only be used for certificate printing.

The online registration process for a certificate form is, first, the operator of the Education and Training Institute will input the blank request. Then, the certification unit submits a blank request. The Ditkapel certification staff will input the initial and final blank serial numbers and upload the receipt. Subsequently, the Kasi for Certification of the Directorate General of Execution shall verify the serial number of the form and approve the request for the form. Certificate forms are distributed and allocated to Educational and Training Institutions / Operators which have received approval from Ditkapel and must be activated before use and must be in accordance with the Minutes of submission of the forms. The use of forms can be monitored in the system and if necessary, they will be compared with manual reports held by each Education and Training Institution using certificate forms.

In its application, the online seafarer certification system still has many weaknesses, one of which is security that can be penetrated by hackers and can unsuspend certain numbers of seafarers and carry out registration. The impact of this weak online certification system is that many seafarers experience theft of personal data.

Efforts that have been made to overcome this are that the Directorate General of Sea Transportation (DJPL) has collaborated with the National Cyber and Crypto Agency (BSSN) to carry out a Security Assessment of the Online Seafarers Certification System Application which was built in 2016 by conducting investigations within the scope of June 2018. until October 2019. The cycle of the security process consists of 4 (four) stages including assessment, protection, detection and response. This Security Assessment deals with related policies, procedures, laws, regulations, budgets and other managerial duties, plus a technical evaluation of security posture.

This scope includes the Transportation Attache of the Indonesian Embassy in Singapore, due to the large number of reports entered there during the research and ground practice of the researchers. The investigative methodology used is by taking logs and analyzing running processes, logs, and source code. BSSN concluded that, there are several things in the system that need to be improved to reduce the risk of attacks from both inside and outside the system.

BSSN and the Ministry of Transportation, in this case Ditkapel, have been collaborating to tackle fake maritime certificates since 2018. However, until the time the

Ths paper is presented in The $4^{\text {th }}$ International Conference on Maritime Education and Training 87 
researchers carried out land practice, the perpetrators who made the fake certificates still persisted in carrying out the syndicate.

Examination procedures have also been tighter when the scope of the Attache of Transportation provides public services in the form of ascending and descending licenses, extending seamen's books and making sailors' books. When delivering the files at counter 1, the maritime certificate in the form of $\mathrm{COE}$ and COC is checked by the competent authority in accordance with the provisions of the Transportation Service and X-Ray, and if there is an oddity, the related seafarer will be interviewed and traced from the UPT where he received the certificate. If it is confirmed to be false and the related UPT has never conducted training with the related seafarers, then the sailor's account is suspended and cannot continue carrying out the procedure.

Every month, the Transportation Attache also reports how many fake diplomas were found during the past month and also attaches evidence related to the number of the seafarers to Ditkapel. However, until now, the existing status quo is still insufficient because when compared to other cases of fake maritime certificates, the same case occurred in North Jakarta and it was found that the perpetrator of the fake maritime certificate was a syndicate.

This syndicate consists of Master Jockeys who are former sailors, jockeys, certificate forgers, providers of blanks and those who hacked into the seaman.dephub.go.id system. One of the members of the syndicate is an honorary employee from the Ministry of Transportation who has access to obtain forms and see conditions within the Ministry of Transportation. The impact of this syndicate caused losses to the state and created a bad image in the eyes of the world regarding Maritime Affairs and the Seafarers Education System in Indonesia according to the police. The North Jakarta Regional Police have analyzed that there are still weaknesses in the registration system for seafarers' skills certificates and the storage area for blanks is still not good, in this case using safe parameters. Other than that,

3.2.3. Seafarers' job recruitment is minimal and risky

Based on data from the official site pelaut.dephub.go.id accessed on March 20, 2020, the number of seafarers has increased annually from 1,062,193 seafarers in 2019 to $1,165,869$ in 2020 , therefore it can be concluded that Indonesia has increased the number of sailors rapidly from various education and training institutions in Indonesia. Meanwhile, the recruitment of seafarers is not only carried out by national companies, but also international companies with foreign flags. Foreign companies recruit Indonesian seafarers for many reasons, such as lower pay due to equivalent diplomas, the same quality of seafarers as countries with good value seafarers such as the Philippines, and the large number of seafarers' human resources who require jobs as seafarers in various places and on various ships. . However, in the field, the demand for jobs and the large number of seafarers who register create inequality so that companies have to do more selection to get proper seafarers to pilot their ships. This selection is what makes the seafarers' competitive attitude increase and the various means taken to get the job and sign on according to company demand. These various methods include increasing competence through education and training, going to school again at the appointed UPT, and using fake maritime certificate manufacturing and registration services. This selection is what makes the seafarers' competitive attitude increase and the various means taken to get the job and sign on according to company demand. These various methods include increasing competence through education and training, going to school again at appointed UPTs, and using fake maritime certificate manufacturing and registration services. This selection is

Ths paper is presented in The $4^{\text {th }}$ International Conference on Maritime Education and Training 88 October $8^{\text {th }}$, 2020, Makassar, Indonesia 
what makes the seafarers' competitive attitude increase and the various means taken to get the job and sign on according to company demand. These various methods include increasing competence through education and training, going to school again at the appointed UPT, and using fake maritime certificate manufacturing and registration services.

The impact of the opportunities and opportunities for seafarers to commit fraud is very risky because it has a direct impact such as the bad image of Indonesian seafarers, and the efforts being made to overcome this are verification of diplomas as well as freezing and reporting to Ditkapel and the Ministry of Transportation for further action.

\section{Conclusion}

4.1. The causes of the prevalence of fake maritime certificates for Indonesian seafarers in Singapore are the deviant social behavior of seafarers, the weak online Indonesian seafarers certification system, and the opportunities and opportunities for seafarers to commit fraud.

4.2. The specific impact of the cause of the rampant fake maritime certificates for Indonesian seafarers is that seafarers find it difficult to find work in Singapore shipping companies, a lack of trust from foreign companies to recruit Indonesian seafarers, and blacklisting of Indonesian seafarers with a certain rank in several companies.

4.3. The steps taken by the Transportation Attaché to resolve cases of fake maritime certificates are to verify the issuance with the relevant education and training institutions, as well as collaborating with the National Cyber Crypto Agency (BSSN) to strengthen the security system for seafarer certification and also coordinate with the Batam Police and Police Riau to resolve cases of fake maritime certificates in accordance with the implementation of the supervisory and inspection functions in accordance with Ministerial Instruction No.4 of 2018.

\section{References}

[1] RI Department of Transportation. 2007, Regulation of the Minister of Transportation Number KM 37 of 2007 concerning Procedures for the Assignment of Civil Servants of the Ministry of Transportation as Transportation Attaches, Transportation Technical Staff, and Staff at Representatives of the Republic of Indonesia Abroad

[2] Ministry of Transportation of the Republic of Indonesia. 2000, Government Regulation Number 7, 2000 concerning Maritime Affairs.

[3] Ministry of Transportation of the Republic of Indonesia. 2008, Regulation of the Minister of Transportation Number KM 30 of 2008 concerning Seafarers' Identity Documents.

[4] Sugiyono. 2013, Educational Research Methods with Quantitative Approaches, Qualitative and R \& D, Bandung, Alfabeta.

[5] Haricahyono, C. 1995, Dimensions of Moral Education, Semarang, Semarang State Teachers' Training College, Semarang Press.

[6] Purnamasari, Deti Mega. 2019, How is Indonesia as a Global Maritime Axis?, Quoted March 23, 2020 from Kompas, https://amp.kompas.com/nasional/read/2019/08/07/08062741/apa-kabar-indonesiasebagai-poros- maritime-world.

Ths paper is presented in The $4^{\text {th }}$ International Conference on Maritime Education and Training 